\title{
Liquid Dosage Forms Extemporaneously Prepared from Commercially Available Products - Considering New Evidence on Stability
}

\author{
Alison Haywood ${ }^{1}$ and Beverley D Glass ${ }^{2}$ \\ ${ }^{1}$ School of Pharmacy, Griffith Health Institute, Griffith University, Gold Coast, Australia. ${ }^{2}$ School of Pharmacy and \\ Molecular Sciences, James Cook University, Townsville, Australia.
}

Received, April 18, 2013; Accepted, June 20, 2013; Published, June 23, 2013.

\begin{abstract}
Although the world's population is ageing and as a result of this an increasing number of patients are experiencing difficulty in swallowing, there remains a lack of commercially available oral liquids for both these older and paediatric patients. This presents a problem to health care professionals, especially the pharmacist in practice, who is often required to provide a solution for these patients by preparing oral liquids extemporaneously from commercially available products. Preparation of these oral liquids is challenging, both due to the lack of pharmacopoeial and stability-indicating formulae and the fact that their stability is not only determined by the active pharmaceutical ingredient, but also the ability of excipients from the commercial product to interact with each other and the active pharmaceutical ingredient. This increases the complexity of the stability considerations to be taken into account within these oral liquids, highlighting the number of parameters to be considered in the extemporaneous preparation of oral liquids.

This paper presents new evidence on the stability of 42 oral liquids prepared from commercially available products, reported on in the literature since the previous review published in 2006. However, unlike the previous review where the stability concerns in $7.2 \%$ of the extemporaneously prepared oral liquids were mainly due to interaction between the active pharmaceutical ingredients and the excipients in the commercial product, most of these stability considerations have been recognised and this has resulted in the authors proposing solutions to these problems prior to the extemporaneous preparation of the oral liquid.

As such this paper also focuses on the increased level of research that has been undertaken to solve previous issues related to stability, especially in terms of the use of commercial products, which is common practice in the extemporaneous preparation of oral liquids.
\end{abstract}

This article is open to POST-PUBLICATION REVIEW. Registered readers (see "For Readers") may comment by clicking on ABSTRACT on the issue's contents page.

\section{INTRODUCTION}

The lack of commercially available oral liquid dosage forms is an ongoing problem for health care providers in many practice settings. Pharmacists are often challenged to provide extemporaneous oral liquids. While these are most commonly provided for paediatric patients where non-standard doses are more easily and accurately measured by using a liquid formulation, adults unable to swallow tablets or capsules and patients receiving medicines via nasogastric or gastrostomy tubes will also benefit from these preparations (1). The world's population is ageing and many people suffer from dysphagia either as a consequence of disease or as part of the ageing process. Elderly patients are more prone to diseases linked to dysphagia, such as Parkinson's disease and Alzheimer's and other dementias, stroke and cancer (2-4). Extemporaneous oral liquids are also needed where, for example, a commercially available oral liquid is discontinued or temporarily unavailable, such as Tamiflu® (oseltamivir) Oral Suspension $(5,6)$.

A number of parameters need to be considered in the formulation of a stable oral liquid. These include chemical, physical, microbiological, therapeutic and toxicological stability evaluations not only taking account of the active pharmaceutical ingredient (API), but also the excipients and packaging of the drug product. The extemporaneous preparation of oral liquids can be complex due to the addition of excipients to improve patient adherence and / or the stability of the final product. Further, due to convenience and availability of ingredients, it is

Corresponding Author: Professor Beverley D Glass, Chair of Pharmacy, School of Pharmacy and Molecular Sciences, James Cook University, Douglas Campus, Townsville, Australia; Email: Beverley.Glass@jcu.edu.au 
common practice for oral liquids to be prepared from commercially available solid dosage forms such as a tablet or capsules. Therefore additional potential interactions may occur between the drug and the excipients in the solid dosage in the prepared oral liquid.

In addition to chemical stability, physical stability, microbial stability and palatability, excipient suitability (e.g. sugar free for diabetic patients) and interactions with packaging materials need to be considered in the preparation of a suitable extemporaneous oral liquid. These considerations are detailed in the discussion.

This review provides new evidence, since the previous review in 2006 (7), of stability data for extemporaneous oral liquids prepared from commercially available dosage forms including tablets, capsules and intravenous preparations. Further, the review outlines important stability considerations and the risk associated with modifying commercial products and provides guidelines to assist the pharmacist in preparing safe, effective and high quality oral liquids.

\section{METHODS}

A review protocol was developed with data identified from MEDLINE, EMBASE, Informit, Google Scholar, reference texts related to the field and reference lists of articles and abstracts from conference proceedings. Searches were current as of April 2013.

Only those liquid dosage forms prepared from commercially available dosage forms were considered, as this is most commonly encountered in practice, where access to raw material as the is not often convenient or even possible. As in the first review (7), only those preparations that included a chemical stability assessment via a stability-indicating high performance liquid chromatography (HPLC) method were included and the oral liquids were considered chemically stable if they retained $\geq 90 \%$ of the initial drug concentration. The reasons for this are detailed in the previous review (7). Those oral liquids that have been previously reported on in the first review have not been included in this paper.

\section{RESULTS}

This review includes 42 examples (Table 1) of oral liquids in practice, prepared by modification of commercial medications, including the methods, excipients, packaging and reasons for their extemporaneous preparation. The outcome of the chemical and physical stability studies conducted is also presented. The highlighted (shaded) areas in Table 1 indicate those preparations that have been further detailed in the discussion.

\section{DISCUSSION}

Of the 42 liquid dosage forms reviewed in the literature, all cases of instability were managed through the addition of specific excipients, illustrating that there is minimum risk associated with these dosage forms and that pharmacists taking cognisance of various factors such as drug stability, mechanisms and routes of degradation, and potential interactions with excipients in the tablets and/or capsules utilised in the formulation are further able to minimise the risk involved. The individual dosage forms displaying stability concerns are discussed below.

\section{Omeprazole and lansoprazole oral liquid dosage forms}

Stability concerns with lansoprazole (20) are related to a slightly acidic $\mathrm{pH}$ of the final formula due to Ora-Blend being buffered to a slightly acidic $\mathrm{pH}$ of $\sim 4.2$. However, this instability has been largely addressed by the addition of $\mathrm{NaHCO}_{3}$. Further, omeprazole is now commercially available as a powder for oral suspension (ZEGERID ${ }^{\circledR}$ Powder for Oral Suspension) which contains $\mathrm{NaHCO}_{3}$, xylitol, sucrose, sucralose, xanthan gum, and flavourings.

\section{Mercaptopurine oral liquid dosage forms}

A study reported on the stability of mercaptopurine, a drug susceptible to oxidation, resulting in the formation of acidic degradants (23). A buffer was therefore investigated to address the increased acidity due to the formation of these degradants. However the buffer resulted in a decreased stability of mercaptopurine, due to the increased $\mathrm{pH}$. This stability issue was addressed by the addition of the antioxidant ascorbic acid which increased the shelf-life from 5 to 11 weeks.

The authors recommended further studies on the microbial safety of these vehicles, since they did not contain preservatives; however this can be addressed by using commercially available vehicles such as Ora-Blend which are adequately preserved.

\section{Temozolomide oral liquid dosage forms}

Temozolomide is a prodrug, which after hydrolysis in an alkaline environment is converted to the active alkylating agent. Solid- 
state temozolomide is thus also susceptible to hydrolytic degradation under accelerated temperature and humidity conditions $\left(40{ }^{\circ} \mathrm{C}\right.$ and $75 \%$ relative humidity), with a change in colour of the white powder first to pink and then brown, an indication that this chemical degradation has occurred. Temozolomide does however also exhibit polymorphism, with powder X-ray crystal structures confirming the identity of three crystalline polymorphs and a monohydrate. Although the powder X-ray diffraction pattern of the commercially available temozolomide is consistent with Form 1, which is non hygroscopic the discolouration of certain brands of tablets on storage raises the question as to which crystal form is present in these tablets (47). Temozolomide oral liquid extemporaneously prepared from commercially available capsules in both (1:1) Ora-Plus: Ora-Sweet and Ora-Plus: Ora-Sweet SF was stored at room temperature (23 ${ }^{\circ} \mathrm{C}$ ) and at $4{ }^{\circ} \mathrm{C}(36)$, with stability confirmed for 1 week in Ora-Plus: Ora-Sweet $(1: 1)$ and 2 weeks in Ora-Plus: Ora-Sweet SF at room temperature (23 ${ }^{\circ} \mathrm{C}$ ) and 60 days at $4^{\circ} \mathrm{C}$. Because of the potential for polymorphism and the detection of crystals in the suspensions within a few days of storage at both temperatures, the excipient povidone K-30 was added to minimise this crystal growth, which if it does occur may result in inaccurate dosing.

The inclusion of povidone K-30 to prevent crystal formation and optimising the $\mathrm{pH}$ at 4 (citric acid) to reduce hydrolytic degradation produced a pharmaceutically acceptable suspension when stored under refrigeration.

\section{Clopidogrel oral liquid dosage forms}

Skillman et al (14) evaluated the stability of clopidogrel $5 \mathrm{mg} / \mathrm{mL}$ suspension prepared in OraPlus and Ora-Sweet and concluded that over $90 \%$ of the initial clopidogrel concentration was retained after 60 days at room temperature or under refrigeration. However, the method used to measure clopidogrel concentration was not chirally selective and failed to consider the potential for isomeric inversion of the active Sclopidogrel to the inactive R-clopidogrel. A later study (14) highlighted the importance of the conversion of the acive $\mathrm{S}$ form to the inactive $\mathrm{R}$ enatiomer. This study determined that $1.5 \%$ and $3 \%$ of S-clopidogrel was converted to the $\mathrm{R}$ enantiomer after storage for 49 days at $4{ }^{\circ} \mathrm{C}$ and $25{ }^{\circ} \mathrm{C}$ respectively. These authors then used this data to estimate the shelf-life assuming $90 \%$ of the original content and recommended an expiry of 1 month under refrigeration and 2 weeks at room temperature $\left(25^{\circ} \mathrm{C}\right)$.

\section{Packaging used in extemporaneous oral liquid preparations}

Ensom et al (19) reported on the stability of lansoprazole $(3 \mathrm{mg} / \mathrm{mL})$ in extemporaneously compounded suspensions (see Table 2). The findings reported here are in contrast with those of a previous study (48) detailed in the first review (7), in which a lansoprazole suspension (3 $\mathrm{mg} / \mathrm{mL}$ ) was stable for only 8 hours when prepared from capsule contents mixed in $100 \mathrm{~mL}$ of $8.4 \% \mathrm{NaHCO}_{3}$ and stored at room temperature $\left(22^{\circ} \mathrm{C}\right)$ in amber-coloured, plastic oral syringes. Although the refrigerated $\left(4^{\circ} \mathrm{C}\right)$ samples in that study were reported to be stable for only 14 days, the refrigerated samples in the current study were stable for 91 days. It has been suggested by the authors that the different storage containers, namely plastic syringes and glass bottles, may account for the difference in stability of lansoprazole suspensions, and that a substance present in the plastic syringes but not in the glass might have reduced the stability of lansoprazole. In addition it was also suggested that the amber syringes stored at room temperature would not have protected the lansoprazole from UV light to the same extent as the suspension stored in the refrigerator, where it is naturally dark (19).

\section{Storage conditions for oral liquids}

It is important to note that refrigerated solutions do not always show increased stability and can have increased problems of caking as demonstrated by the study by Aliabadi et al (23) with a refrigerated suspension of mercaptopurine. This emphasises the importance of stability studies for specific drugs and the benefits of using a vehicle containing appropriate suspending agents.

\section{Considerations in the extemporaneous preparation of oral liquids}

When considering the suitability of an extemporaneous oral liquid, a number of factors, in addition to chemical stability need to be considered (Table 2). This includes physical stability, microbial stability, palatability, excipient suitability (e.g. sugar free for diabetic patients), interactions with packaging materials, accurate compounding procedures including calculations and cost. 
Table 2. Considerations for the preparation of a stable, effective, quality oral liquid

\begin{tabular}{|c|c|c|}
\hline \multicolumn{2}{|l|}{ Consideration } & Potential excipients required \\
\hline Chemical stability & $\begin{array}{l}\text { Including the stability of the API and the effect } \\
\text { of tablet excipients in solution; pH stability and } \\
\text { the need for buffers. }\end{array}$ & $\begin{array}{l}\text { Antioxidants } \\
\text { EDTA } \\
\text { Buffers }\end{array}$ \\
\hline Physical stability & $\begin{array}{l}\text { Caking, crystal growth, resuspension and the } \\
\text { ability to administer an accurate dose. }\end{array}$ & $\begin{array}{l}\text { Suspending agents } \\
\text { Antifoaming agents }\end{array}$ \\
\hline $\begin{array}{l}\text { Microbial stability and } \\
\text { shelf-life }\end{array}$ & Adequate preservation. & Preservatives \\
\hline Palatability & Sufficient masking of bitter drugs. & $\begin{array}{l}\text { Sweeteners } \\
\text { Flavours } \\
\text { Colours }\end{array}$ \\
\hline Excipient suitability & $\begin{array}{l}\text { Alcohol free for paediatric patients; sugar free } \\
\text { for diabetic patients. }\end{array}$ & $\begin{array}{l}\text { Alcohol free vehicles } \\
\text { Artificial sweeteners }\end{array}$ \\
\hline Packaging & $\begin{array}{l}\text { Light protection; child safety; interactions with } \\
\text { packaging materials (glass or plastic). }\end{array}$ & \\
\hline Bioavailability & $\begin{array}{l}\text { Absorption and therapeutic efficacy of a drug in } \\
\text { a suspension compounded from crushed tablets } \\
\text { is unlikely to differ appreciably from those of } \\
\text { the original dosage form. }\end{array}$ & \\
\hline Cost & $\begin{array}{l}\text { Availability of starting materials; staff } \\
\text { preparation time. }\end{array}$ & \\
\hline $\begin{array}{l}\text { Compounding } \\
\text { considerations }\end{array}$ & $\begin{array}{l}\text { Accurate measurement; appropriate equipment } \\
\text { and facilities; exposure of sensitive ingredients } \\
\text { (to light) during compounding; water source (no } \\
\text { ions). }\end{array}$ & \\
\hline Shelf-life & $\begin{array}{l}\text { Assigning an appropriate beyond use date/ shelf } \\
\text { life. }\end{array}$ & \\
\hline Dose calculations & $\begin{array}{l}\text { For example, not accounting for the weight of } \\
\text { tablet excipients when calculating the weight of } \\
\text { the API. }\end{array}$ & \\
\hline
\end{tabular}

From the Table 2 it can be seen that the design of an oral liquid from first principles is a lengthy process and would require careful consideration of a number of factors:

(i) chemical stability includes considering the potential degradation of the API by pathways such as oxidation, hydrolysis, photolysis or thermolysis, and any potential interactions between the API, the excipients in the vehicle, the excipients in the original dosage form (e.g. tablet or capsule) and the packaging.

(ii) physical stability includes considering resuspension and the ability to administer an accurate dose, antifoaming agents to prevent excessive foaming from vigorous shaking prior to administering a dose, and caking or crystal growth that may arise during storage.

(iii) microbial stability includes the use of preservatives at a suitable strength to prevent microbial growth in a predominantly water based preparation. A recent study by Ghulam et al (49), showed that various suspending vehicles failed the BP 2007 efficacy of preservation tests when diluted in ratios greater than 1:1, and cautioned that such dilution represents a potential biohazard, especially to premature, newborn, or immunocompromised children. Another study by Salgado et al (50) on the microbial stability of spironolactone in Simple syrup NF, demonstrated the importance of the use of preservatives, since microbial contamination occurred in the preparation, even when stored at low temperatures.

(iv) palatability includes the use of suitable flavours and sweeteners to mask bitter drugs, especially with young patients. It has also been suggested that administering chocolate syrup before medication administration or mixing the preparation with chocolate syrup (1:1 by volume) immediately before administration is recommended to mask the bitter aftertaste and improve 
palatability, for extremely bitter drugs $(18,28,30)$.

(v) excipient suitability includes limiting cosolvents such as alcohol for children and providing sugar free preparations for diabetic patients.

(vi) packaging includes the use of amber containers not only for APIs sensitive to light, but also those ingredients in the vehicle, such as colours and flavours that may also be sensitive to light. Provision of child safety packaging is particularly important for oral liquids where a significant dose could be inadvertently administered when compared to tablets or capsules.

(vii) bioavailability. It has been suggested that absorption and therapeutic efficacy of a drug in a suspension compounded from crushed tablets is unlikely to differ appreciably from those of the original dosage form (35). Careful consideration should be given when using commercial products designed for administration via another route (e.g. intravenous preparations) since there may be differences in bioavailability when these products are administered orally.

(viii)cost, compounding considerations and shelf-life. The availability of starting materials and excipients and staff preparation time are important considerations $(9,51,52)$, as is access to appropriate facilities and equipment and accurate calculations of ingredients in the final preparation. Some API's are extremely sensitive to light, showing significant degradation in only a few hours, therefore exposure to light needs to be minimised during preparation. The source of the water used has also been shown to cause problems (53). Assigning an appropriate beyond use date or shelflife in the absence of specific stability studies is also challenging, with many preparations given a very short shelf-life for safety purposes.

(ix)dose calculations. A study on the stability of a $1 \mathrm{mg} / \mathrm{ml}$ tacrolimus suspension (34) has shown that careful consideration of the strength of the oral liquid (namely $1 \mathrm{mg} / \mathrm{mL}$ as opposed to decimal amounts per $\mathrm{mL}$ ) will facilitate several aspects of clinical care, For example, the 1:1 ratio of drug to suspension volume will decrease the frequency of patient medication errors, as it allows for a more simplified and straightforward drug administration. This will also facilitate easier discharge medication instructions or any follow-up discharge instruction in the outpatient clinic when confirming and verifying dosing. Further, incremental dosing with the $1 \mathrm{mg} / \mathrm{ml}$ suspension allows for more accurate adjustment of therapy based on monitoring blood levels and paediatric dosing could result in better patient adherence owing to the small volume required for dosing.

\section{Commercially available oral liquid vehicles}

Commercially available vehicles, such as OraPlus and Ora-Sweet and Ora-Sweet SF are a convenient resource for pharmacists, since many practice settings may not stock a wide variety of excipients and many of the stability studies in the literature on oral liquids prepared extemporaneously utilise these commercial vehicles, as seen in Table 1. A number of medicines are stable at an acidic $\mathrm{pH}$, for example thalidomide is not stable in a solution with a $\mathrm{pH}$ of greater than or equal to 6.0 (37). All of the above vehicles are buffered to a slightly acidic $\mathrm{pH}$ ( $\mathrm{pH} 4.2)$ to reduce the degradation of medicinal agents through oxidation. The vehicles also contain effective preservatives, therefore microbial testing is not needed (22). Ora-Plus is a translucent, milky white oral suspending vehicle that can be diluted up to $50 \%$ or more with other ingredients and still retain appropriate properties as a suspending agent. It also contains an antifoaming agent, simethicone, to allow for vigorous shaking of the suspension with minimal production of foam. Ora-Sweet syrup is a flavouring vehicle for oral extemporaneous preparations. It contains glycerin and sorbital to prevent "cap-lock", a problem associated with many syrups, due to sugar crystallization, and will retain its flavouring properties when diluted up to $50 \%$ with water or suspending agents. Ora-Sweet $\mathrm{SF}$ is a sugar-free version of Ora-Sweet with similar properties. Ora-Plus and either Ora-Sweet or Ora-Sweet SF can be combined in a 50/50 ratio to produce a pleasant tasting elegant suspension. The original formulas for the Ora-range of vehicles are available in the United States Pharmacopoeia/ National Formulary (USP/NF) and are referred to as Vehicle for Oral Solution NF (i.e. Ora-Sweet), Vehicle for Oral Suspension $N F$ (i.e. Ora-Plus), and Vehicle for Oral Solution, Sugar Free NF (i.e. Ora-Sweet SF) (54). 
A recent study (55) on the content uniformity of six different suspensions compounded from nifedipine tablets, showed that the suspensions compounded with methylcellulose $1 \%$ / syrup NF or hypromellose $1 \%$ required mixing by inverting the bottle 10 to15 times, while the commercially available suspension vehicles (namely, OraPlus/Ora-Sweet, Ora-Plus/Ora-Sweet SF and SyrSpend SF Cherry) complied with the pharmacopoeial content uniformity test if the bottle was inverted only three times. This highlights the benefits of utilising commercially available vehicles.

Further usefulness of commercially available vehicles is highlighted in a review of the stability of captopril oral liquids (53). Due to the susceptibility of captopril to oxidation, the use of water-based captopril solutions is not recommended. This is due to the potential for the variable quality of water, particularly in terms of its metal ion content, to facilitate the oxidative degradation of captopril. The previous review (7) detailed a number of studies and the associated stability concerns with compounding captopril oral liquids. It has been suggested that alternative therapeutic agents such as lisinopril and ramipril should be preferentially used due to their improved stability in oral formulations, or commercially available captopril oral liquids sourced.

\section{Management of oral liquid preparations in practice}

A recent review by Lam (56) on the extemporaneous preparation of oral liquid formulations for anticancer drugs showed that compounding formulae are available for only 46 $\%$ of oral anticancer agents and that there is a paucity of data in terms of stability, bioequivalence, and safety of these extemporaneously prepared oral formulations. The review detailed the challenges that health care providers, patients, and caregivers face with the limited availability of oral liquid formulations. Caregivers are often at an increased risk of exposure to these hazardous drugs when challenged with an oral tablet or capsule that the patient cannot swallow. The review also highlighted the important role that oncology pharmacists, as well as community pharmacists, can play as a resource for educating and monitoring patients receiving oral chemotherapy to ensure dosing accuracy, safe administration, and proper disposal of hazardous drugs.
The first review provided a flow chart, with explanations, for the management of oral liquids in practice (7). Due to the complexities involved in extemporaneously preparing oral liquids, it highlighted that (i) pharmacists should always consider a commercially available product (i.e. this may not necessarily be limited to an oral liquid and may include other alternative dosage forms, such as a transdermal patch or a dispersible tablet); (ii) if no suitable commercial product exists, a therapeutic alternative that is available in a suitable dosage form may be considered, in consultation with the prescribing doctor, and (iii) the importation of suitable oral liquid medicines licensed in other countries may also be considered.

Should none of these measures prove successful, a suitable formula for an oral liquid with a proven stability profile should be sought in the literature. Useful resources include, Allen's Compounded Formulations (57), Paediatric Drug Formulations (58), Trissel's Stability of Compounded Formulations (1), journals such as the International Journal of Pharmaceutical Compounding and the American Journal of Health-System Pharmacy, and the current and previous review article (7) showing examples of oral liquid dosage forms prepared by modifying an existing commercial medication.

Stability studies in the literature allow for increased shelf-life and cost savings, in addition to providing evidence for stable products. Further, the recent availability of commercial liquid vehicles in many countries now provides pharmacists with a convenient resource for preparing an oral liquid formulation. It is also promising to note that procedures to prepare stable oral liquids from commercial solid dosage forms have been provided by manufacturers in cases where an oral liquid is not available or temporarily out of stock (Table 3 ).

\section{Alternatives to preparing oral liquids}

The previous review (7) provided details on dispersing tablets or capsules in water or mixing them with food immediately prior to administration, and the provision of powder packets in cases where the preparation of oral liquid dosage forms are not feasible. The disadvantages of these methods were outlined, namely potential for dosing inaccuracies, poor palatability leading to adherence issues, and risks associated with carers or patients crushing tablets which should not be crushed (e.g. sustained release tablets). 
Table 3. Examples of instructions provided by manufacturers for the preparation of oral liquids

\begin{tabular}{|c|c|c|c|c|}
\hline $\begin{array}{l}\text { Drug Product } \\
\text { with reference }\end{array}$ & API & Excipients & Packaging & Stability study data \\
\hline Tamiflu® $(59,60)$ & Oseltamivir & $\begin{array}{l}2 \text { vehicles: Cherry Syrup; } \\
\text { Ora-Sweet SF }\end{array}$ & $\begin{array}{l}\text { Amber plastic } \\
\text { bottle }\end{array}$ & $\begin{array}{l}6 \mathrm{mg} / \mathrm{mL} \text { suspension } \\
\text { stable for } 35 \text { days at } 2-8 \\
{ }^{\circ} \mathrm{C} \text { and } 5 \text { days at } 25^{\circ} \mathrm{C} .\end{array}$ \\
\hline $\begin{array}{l}\text { Zestril }{ }^{\circledR}, \\
\text { Prinivil }{ }^{\circledR}(61,62)\end{array}$ & Lisinopril & $\begin{array}{l}\text { Vehicle: Purified water, } \\
\text { Bicitra }{ }^{\circledR} \text { diluent and Ora- } \\
\text { Sweet SF® }\end{array}$ & $\begin{array}{l}\text { Polyethylene } \\
\text { terephthalate } \\
\text { (PET) bottle }\end{array}$ & $\begin{array}{l}1 \mathrm{mg} / \mathrm{mL} \text { suspension } \\
\text { stable for four weeks at } \\
25^{\circ} \mathrm{C} \text {. }\end{array}$ \\
\hline $\operatorname{Rifadin}{ }^{\circledR}(63)$ & Rifampin & $\begin{array}{l}4 \text { vehicles: Simple Syrup } \\
\text { NF; Simple Syrup (Humco } \\
\text { Laboratories); Syrpalta }{ }^{\circledR} \\
\text { Syrup (Emerson } \\
\text { Laboratories); or } \\
\text { Raspberry Syrup (Humco } \\
\text { Laboratories) }\end{array}$ & $\begin{array}{l}\text { Amber glass or } \\
\text { plastic (high } \\
\text { density } \\
\text { polyethylene, } \\
\text { polypropylene, or } \\
\text { polycarbonate) } \\
\text { prescription bottle }\end{array}$ & $\begin{array}{l}10 \mathrm{mg} / \mathrm{mL} \text { suspension } \\
\text { stable for four weeks at } \\
2-8^{\circ} \mathrm{C} \text { and } 25 \pm 3{ }^{\circ} \mathrm{C} .\end{array}$ \\
\hline
\end{tabular}

The review by Lam (56) provides detailed guidelines in an Appendix for patients on what to do if they cannot swallow their oral anticancer medication.

\section{Solid dosage forms that should not be crushed}

Information on the appropriateness of crushing tablets or opening capsules is available through resources such as the approved product information and the CMI (Consumer Medicine Information) of the commercial solid dosage form. Compiled lists of medicines that should not be crushed or modified are available, such as the Australian Don't Rush to Crush Handbook (64), the Handbook of Drug Administration via Enteral Feeding Tubes (65), the Australian Medicines Handbook (AMH) Aged Care Companion (66) and electronic resources such as the list provided by the Institute for Safe Medication Practices (67).

\section{Short term stability of crushed medicines in food thickeners or water}

A recent study reported on the short term compatibility of risedronate sodium tablets with different food thickeners, namely Milani Thickit ${ }^{\circ}$, Resource Thicken Up ${ }^{\circledR}$, Thik \& Clear ${ }^{\circledR}$, Hormel Thick \& Easy ${ }^{\circledR}$, and Hormel NutraThik ${ }^{\circledR}$ (68). A risedronate sodium $35-\mathrm{mg}$ tablet was added to a beaker and allowed to disintegrate without agitation. After two minutes, the water was stirred with a plastic spoon and an additional $4 \mathrm{oz}$ of water was added to each beaker and stirred briskly for 30 seconds. The recommended amount of each food thickener was then added to each beaker. The risedronate tablets were shown to be stable for 24 hours with each of the food thickeners.

\section{CONCLUSION}

Orals liquids for certain drugs are often not commercially available, due to market size and the many physicochemical factors that need to be considered when formulating a liquid dosage form (69). Since the physicochemical stability of a drug does not confirm either its safety or efficacy in a patient, there are a number of factors, including exercising good judgement, that the pharmacist must take into account when deciding to compound an oral liquid (70). The fact that the stability of an extemporaneous formulation prepared from commercially available products cannot be predicted based on a formulation using the pure drug powder, due to the effect of excipients, was highlighted in the previous review where 6 out of $83(7.2 \%)$ oral liquids presented with stability concerns, largely due to drugexcipient interactions. This review, which includes 42 oral liquids extemporaneously prepared by modifying existing commercial dosage forms presents 6 out of the 42 orals liquids including the four APIs, clopidrogrel, lansoprazole , temozolomide, and mercaptopurine for discussion.

However, it must be noted that the research and skill base in compounding has evolved since the previous review and that many improvements have been made to address the various formulation and stability issues in preparing extemporaneous oral liquids, from commercially available products, which is now common practice.

This review thus presents more complex stability issues, where the authors have proposed the inclusion of specific ingredients (excipients) to address some of the stability problems that have been identified in the past, including: the $\mathrm{pH}$ 
adjustment of lansoprazole extemporaneous oral liquids by the addition of $\mathrm{NaHCO}_{3}$ and the commercial availability of an oral suspension; the inclusion of antioxidants in mercaptopurine oral liquid; the addition of povidone K-30 to prevent crystal growth and citric acid to optimise $\mathrm{pH}$ in temozolomide oral liquid; and the adjustment of storage conditions to prevent enantiomeric conversion of clopidogrel.

This improved understanding of the role of excipients in the stability of extemporaneously prepared oral liquids from commercially available products will allow the pharmacist to meet the challenge in making an informed judgement when asked to address the needs of patients requiring the compounding of oral liquids.

\section{ACKNOWLEDGEMENTS}

The authors wish to acknowledge the support of James Cook University, Townsville and Griffith University, Gold Coast, Australia.

\section{REFERENCES}

1. Trissel LA. 2009. Trissel's Stability of Compounded Formulations. 4th ed. ed., Washington, DC: American Pharmacists Association.

2. Kawamura O, Easterling C, Aslam M, Rittmann T, Hofmann C, Shaker R 2004. Laryngo-upper esophageal sphincter contractile reflex in humans deteriorates with age. Gastroenterology 127(1):57-64.

3. Morris H 2005. Administering drugs to patients with swallowing difficulties. Nursing Times 101(39):28-30.

4. Ren J, Xie P, Lang IM, Bardan E, Sui Z, Shaker R 2000. Deterioration of the pharyngo-UES contractile reflex in the elderly. Laryngoscope 110(9):1563-1566.

5. Voudrie MA, Allen DB 2010. Stability of Oseltamivir Phosphate in SyrSpend SF, Cherry Syrup, and SyrSpend SF (For Reconstitution). IJPC 14(1):82-85.

6. Winiarski AP, Infeld MH, Tscherne R, Bachynsky M, Rucki R, Nagano-Mate K 2007. Preparation and stability of extemporaneous oral liquid formulations of oseltamivir using commercially available capsules. J Am Pharm Assoc (2003) 47(6):747-755.

7. Glass BD, Haywood A 2006. Stability considerations in liquid dosage forms extemporaneously prepared from commercially available products. Journal of Pharmacy and Pharmaceutical Sciences 9(3):398-426.

8. Fohl AL, Johnson CE, Cober MP 2011. Stability of extemporaneously prepared acetylcysteine $1 \%$ and $10 \%$ solutions for treatment of meconium ileus. Am J Health Syst Pharm 68(1):69-72.

9. Kiser TH, Oldland AR, Fish DN 2007. Stability of acetylcysteine solution repackaged in oral syringes and associated cost savings. Am J Health Syst Pharm 64(7):762-766.

10. Siden R, Johnson CE 2008. Stability of a flavored formulation of acetylcysteine for oral administration. Am J Health Syst Pharm 65(6):558-561.

11. Dupuis LL, Lingertat-Walsh K, Walker SE 2009. Stability of an extemporaneous oral liquid aprepitant formulation. Support Care Cancer 17(6):701-706.

12. Donnelly RF, Pascuet E, Ma C, Vaillancourt R 2009. Stability of celecoxib oral suspension. Can J Hosp Pharm 62(6):464-468.

13. Skillman KL, Caruthers RL, Johnson CE 2010. Stability of an extemporaneously prepared clopidogrel oral suspension. Am J Health Syst Pharm 67(7):559-561.

14. Mihaila B, Ellis D, Rozek T, Milne R 2012. Chiral Stability Study of Oral Liquid Clopidogrel Formulations for Infants. J Pharm Prac Res 42(2):106-110.

15. Walker SE, Baker D, Law S 2005. Stability of clozapine stored in oral suspension vehicles at room temperature. Can J Hosp Pharm 58(5):279284.

16. Kennedy R, Groepper D, Tagen M, Christensen R, Navid F, Gajjar A, Stewart CF 2010. Stability of cyclophosphamide in extemporaneous oral suspensions. Ann Pharmacother 44(2):295-301.

17. Chou J, Decarie D, Dumont RJ, Ensom MH 2001. Stability of dexamethasone in extemporaneously prepared oral suspensions. Can J Hosp Pharm 54(2):97-103.

18. Cober MP, Johnson CE, Sudekum D, Penprase K 2011. Stability of extemporaneously prepared glycopyrrolate oral suspensions. Am J Health Syst Pharm 68(9):843-845.

19. Ensom MH, Decarie D, Sheppard I 2007. Stability of lansoprazole in extemporaneously compounded suspensions for nasogastric or oral administration. Can J Hosp Pharm 60(3):184-191.

20. Melkoumov A, Soukrati A, Elkin I, Forest JM, Hildgen P, Leclair G 2011. Quality evaluation of extemporaneous delayed-release liquid formulations of lansoprazole. Am J Health Syst Pharm 68(21):2069-2074.

21. Ensom MH, Decarie D, Rudolph S 2011. Stability of levetiracetam in extemporaneously compounded suspensions. Can J Hosp Pharm 64(3):207-211.

22. Johnson CE, Cober MP, Thome T, Rouse E 2011. Stability of an extemporaneous alcohol-free melatonin suspension. Am J Health Syst Pharm 68(5):420-423.

23. Aliabadi HM, Romanick M, Desai S, Lavasanifar A 2008. Effect of buffer and antioxidant on 
stability of a mercaptopurine suspension. Am J Health Syst Pharm 65(5):441-447.

24. Hutchinson DJ, Johnson CE, Klein KC 2009. Stability of extemporaneously prepared moxifloxacin oral suspensions. Am J Health Syst Pharm 66(7):665-667.

25. Johnson CE, Cober MP, Ludwig JL 2007. Stability of partial doses of omeprazole-sodium bicarbonate oral suspension. Ann Pharmacother 41(12):1954-1961.

26. Burnett JE, Balkin ER 2006. Stability and viscosity of a flavored omeprazole oral suspension for pediatric use. Am J Health Syst Pharm 63(22):2240-2247.

27. Johnson CE, Cober MP, Hawkins KA, Julian JD 2011. Stability of extemporaneously prepared oxandrolone oral suspensions. Am J Health Syst Pharm 68(6):519-521.

28. Cober MP, Johnson CE 2007. Stability of an extemporaneously prepared alcohol-free phenobarbital suspension. Am J Health Syst Pharm 64(6):644-646.

29. Caruthers RL, Johnson CE 2007. Stability of extemporaneously prepared sodium phenylbutyrate oral suspensions. Am J Health Syst Pharm 64(14):1513-1515.

30. Cober MP, Johnson CE, Lee J, Currie K 2010. Stability of extemporaneously prepared rifaximin oral suspensions. Am J Health Syst Pharm 67(4):287-289.

31. Hutchinson DJ, Liou Y, Best R, Zhao F 2010. Stability of extemporaneously prepared rufinamide oral suspensions. Ann Pharmacother 44(3):462-465.

32. Lingertat-Walsh K, Walker SE, Law S, Abesamis M, Sales P 2006. Stability of Sulfasalazine Oral Suspension. Can J Hosp Pharm 59(4):194-200.

33. Navid F, Christensen R, Minkin P, Stewart CF, Furman WL, Baker S 2008. Stability of sunitinib in oral suspension. Ann Pharmacother 42(7):962966.

34. Elefante A, Muindi J, West K, Dunford L, Abel S, Paplham P, Brown K, Hahn T, Padmanabhan S, Battiwalla M, McCarthy PL 2006. Long-term stability of a patient-convenient $1 \mathrm{mg} / \mathrm{ml}$ suspension of tacrolimus for accurate maintenance of stable therapeutic levels. Bone Marrow Transplant 37(8):781-784.

35. Pettit RS, Johnson CE, Caruthers RL 2012. Stability of an extemporaneously prepared tadalafil suspension. Am J Health Syst Pharm 69(7):592-594.

36. Trissel LA, Zhang Y, Koontz S 2006. Temozolomide Stability in Extemporaneously Compounded Oral Suspensions. International Journal of Pharmaceutical Compounding 10(5):396-399.

37. Kraft S, Johnson CE, Tyler RP 2012. Stability of an extemporaneously prepared thalidomide suspension. Am J Health Syst Pharm 69(1):56-58.
38. Hopkins AM, Sharley NA, Tang CD 2012. Stability Study of a Thalidomide Suspension. J Pharm Prac Res 42(2):115-117.

39. Aliabadi HM, Romanick M, Somayaji V, Mahdipoor P, Lavasanifar A 2011. Stability of compounded thioguanine oral suspensions. Am J Health Syst Pharm 68(10):900-908.

40. Whaley PA, Voudrie MA 2012. Stability of Vancomycin in SyrSpend SF. International Journal of Pharmaceutical Compounding 16(2):167-169.

41. Donnelly RF, Wong K, Goddard R, Johanson C 2011. Stability of Venlafaxine Immediate-Release Suspensions. International Journal of Pharmaceutical Compounding 15(1):81-84.

42. Kervela G-J, Castagnet S, Chiadmi F, Schlatter J, Benabadji Z, Cisternino S, Fontan JE 2009. Assessment of stability in extemporaneously prepared venlafaxine solutions. european Journal of Hospital Pharmacy Practice 15(4):30-32.

43. De Rosa NF, Sharley NA 2008. Stability of Venlafaxine Hydrochloride Liquid Formulations Suitable for Administration via Enteral Feeding Tubes. J Pharm Prac Res 38(3):212-215.

44. Sharley NA, Yu AMC, Williams DB 2007. Stability of Mixtures Formulated from Warfarin Tablets or Powder. J Pharm Prac Res 37(2):95-97.

45. Green K, Parish RC 2010. Stability of ziprasidone mesylate in an extemporaneously compounded oral solution. J Pediatr Pharmacol Ther 15(2):138-141.

46. Abobo CV, Wei B, Liang D 2009. Stability of zonisamide in extemporaneously compounded oral suspensions. Am J Health Syst Pharm 66(12):1105-1109.

47. Babu NJ, Sanphui P, Nangia A 2012. Crystal engineering of stable temozolomide cocrystals. Chem Asian J 7(10):2274-2285.

48. DiGiacinto JL, Olsen KM, Bergman KL, Hoie EB 2000. Stability of suspension formulations of lansoprazole and omeprazole stored in ambercolored plastic oral syringes. Ann Pharmacother 34(5):600-605.

49. Ghulam A, Keen K, Tuleu C, Wong IC, Long PF 2007. Poor preservation efficacy versus quality and safety of pediatric extemporaneous liquids. Ann Pharmacother 41(5):857-860.

50. Salgado AC, Rosa ML, Duarte MA, Almeida AJ 2005. Stability of spironolactone in an extemporaneously prepared aqueous suspension: the importance of microbiological quality of compounded paediatric formulations. Eur J Hosp Pharm Sci 11(3):68-73.

51. Shah RB, Prasanna HR, Rothman B, Khan MA 2008. Stability of ranitidine syrup re-packaged in unit-dose containers. Am J Health Syst Pharm 65(4):325-329.

52. Milne CP, Bruss JB 2008. The economics of pediatric formulation development for off-patent drugs. Clin Ther 30(11):2133-2145. 
53. Lowey A, Jackson M 2008. How to ensure the quality and safety of unlicensed oral medicines. The Pharmaceutical Journal 281:240.

54. US Pharmacopeia - National Formulary (USP 36NF 31) Online. NF monographs: Vehicle for Oral Solution, Vehicle for Oral Solution Sugar Free and Vehicle for Oral Suspension. ed., Rockville, MD: United States Pharmacopeial Convention.

55. Helin-Tanninen M, Autio K, Keski-Rahkonen P, Naaranlahti T, K. J 2012. Comparison of six different suspension vehicles in compounding of oral extemporaneous nifedipine suspension for paediatric patients. European journal of hospital pharmacy doi:10.1136/ejhpharm-2011-000159

56. Lam MS 2011. Extemporaneous compounding of oral liquid dosage formulations and alternative drug delivery methods for anticancer drugs. Pharmacotherapy 31(2):164-192.

57. Allen LVJ. 2003. Allen's compounded formulations: the complete US pharmacist collection. ed., Washington DC: American Pharmaceutical Association.

58. Nahata MC, Pai VB. 2011. Pediatric drug formulations. 6th ed. ed., Cincinnati.

59. Emergency Compounding of an Oral Suspension from Tamiflu $75 \mathrm{mg}$ Capsules (Final Concentration $15 \quad \mathrm{mg} / \mathrm{mL}$ ). http:/www.fda.gov/Drugs/DrugSafety/Postmarket DrugSafetyInformationforPatientsandProviders/uc m183878.htm [accessed: 11/03/2013]. ed.

60. Tamiflu. Extemporaneous Preparation. http:/www.tamiflu.com/hcp/resources/hcp_resour ces_pharmacists.jsp [accessed: 11/03/2013]. ed.

61. Prinivil ${ }^{\circledR} \quad$ tablets. http://www.merck.com/product/usa/pi_circulars/p/ prinivil/prinivil_pi.pdf [accessed: $11 / 0 \overline{3} / 2013$ ]. ed.
62. Zestril ${ }^{\circledR} \quad$ tablets. http://www1.astrazenecaus.com/pi/zestrillpv.pdf [accessed: 11/03/2013]. ed.

63. Rifadin ${ }^{\circledR} \quad$ capsule. http://dailymed.nlm.nih.gov/dailymed/archives/fda DrugInfo.cfm? archiveid=8618 [accessed: 11/03/2013]. ed.

64. Burridge N, Deidun D. 2012. Australian Don't Rush to Crush Handbook. ed., Collingwood: Society of Hospital Pharmacists of Australia. p 650.

65. White R, Bradnam V. 2007. Handbook of Drug Administration via Enteral Feeding Tubes. ed., London: Pharmaceutical Press.

66. AMH. 2006. Australian medicines handbook. Drug Choice Companion: Aged Care, 2nd ed. ed., Adelaide: Australian Medicines Handbook Pty Ltd.

67. Mitchell JF. 2011. Oral dosage forms that should not be crushed. Institute for Safe Medication Practices, 7 July 2011, Available from www.ismp.org/tools/donotcrush.pdf. ed.

68. Dansereau RJ, Crail DJ 2008. Compatibility of risedronate sodium tablets with food thickeners. Am J Health Syst Pharm 65(22):2133-2136.

69. Nahata MC, Morosco RS, Leguire LE 2000. Development of two stable oral suspensions of levodopa-carbidopa for children with amblyopia. J Pediatr Ophthalmol Strabismus 37(6):333-337.

70. Lim LY, Tan LL, Chan EW, Yow KL, Chan SY, Ho PC 1997. Stability of phenoxybenzamine hydrochloride in various vehicles. Am J Health Syst Pharm 54(18):2073-2078. 


\begin{tabular}{|c|c|c|c|c|c|c|}
\hline \multirow[t]{2}{*}{ API with reference } & \multicolumn{2}{|c|}{$\begin{array}{l}\text { Extemporaneous } \\
\text { modification }\end{array}$} & \multirow[t]{2}{*}{ Excipients } & \multirow[t]{2}{*}{ Packaging } & \multirow[t]{2}{*}{ Stability study data } & \multirow[t]{2}{*}{ Stability considerations } \\
\hline & How? & Why? & & & & \\
\hline Acetylcysteine (8) & 1e & $2 a, 2 c$ & $\begin{array}{l}\text { Vehicle: bacteriostatic } 0.9 \% \\
\text { sodium chloride for injection. }\end{array}$ & $3 b$ (amber) & $\begin{array}{l}\text { 4a. } 10 \mathrm{mg} / \mathrm{mL} \text { and } 100 \mathrm{mg} / \mathrm{mL} \\
\text { solutions were stable for } 60 \text { days } \\
\text { at } 20-25^{\circ} \mathrm{C} \text {. }\end{array}$ & $\begin{array}{l}\text { API sensitive to oxidation. } \\
\text { Note inhalation solution } \\
\text { contains EDTA. }\end{array}$ \\
\hline Acetylcysteine (9) & $1 \mathrm{e}$ & $2 \mathrm{a}$ & $\begin{array}{l}\text { None. Bulk inhalation preparation } \\
\text { repackaged into oral syringes. }\end{array}$ & $3 \mathrm{c}$ & $\begin{array}{l}\text { 4a. } 600 \mathrm{mg} / 3 \mathrm{~mL} \text { solution was } \\
\text { stable for } 6 \text { months at } 3-5^{\circ} \mathrm{C} \text { and } \\
23-25^{\circ} \mathrm{C} \text {. }\end{array}$ & \\
\hline Acetylcysteine (10) & $1 \mathrm{e}$ & * & $\begin{array}{l}\text { Vehicle: } 1: 1 \text { Sweetener and } \\
\text { strawberry creamsicle flavouring } \\
\text { (FLAVORx Inc). }\end{array}$ & 3b (amber) & $\begin{array}{l}\text { 4a. } 86.5 \mathrm{mg} / \mathrm{mL} \text { solution was } \\
\text { stable for } 35 \text { days at } 3-5^{\circ} \mathrm{C} \text { and } \\
23-25^{\circ} \mathrm{C} \text {. }\end{array}$ & $\begin{array}{l}\text { Offensive smell and taste } \\
\text { was effectively masked. }\end{array}$ \\
\hline Aprepitant (11) & $1 b$ & $2 \mathrm{a}$ & Vehicle: Ora-Blend & $\begin{array}{l}\text { 3a (amber); } \\
\text { 3b (amber) }\end{array}$ & $\begin{array}{l}\text { 4a. } 20-\mathrm{mg} / \mathrm{mL} \text { suspension was } \\
\text { stable for } 90 \text { days at } 4^{\circ} \mathrm{C} \text { in amber } \\
\text { glass or plastic. Storage at } 23^{\circ} \mathrm{C} \\
\text { accelerated degradation of the } \\
\text { API. }\end{array}$ & \\
\hline Celecoxib (12) & $1 b$ & $2 \mathrm{a}, 2 \mathrm{~b}$ & Vehicle: Ora-Blend & $3 b$ (amber) & $\begin{array}{l}\text { 4a. } 10 \mathrm{mg} / \mathrm{mL} \text { suspension was } \\
\text { stable for } 93 \text { days at } 5{ }^{\circ} \mathrm{C} \text { and } 23 \\
{ }^{\circ} \mathrm{C} \text {. }\end{array}$ & \\
\hline Clopidogrel (13) & $1 \mathrm{a}$ & $2 \mathrm{a}$ & $\begin{array}{l}\text { Vehicle: 1:1 Ora-Sweet: Ora- } \\
\text { Plus. }\end{array}$ & $3 b$ (amber) & $\begin{array}{l}4 \mathrm{a} .5 \mathrm{mg} / \mathrm{mL} \text { suspension was } \\
\text { stable for } 60 \text { days at } 2-8{ }^{\circ} \mathrm{C} \text { and } \\
23-25^{\circ} \mathrm{C} \text {. }\end{array}$ & $\begin{array}{l}\text { Bitter aftertaste intensified } \\
\text { slightly between } 28-60 \\
\text { days, but remained fairly } \\
\text { mild. }\end{array}$ \\
\hline Clopidogrel (14) & $1 \mathrm{a}$ & $2 \mathrm{a}$ & $\begin{array}{l}\text { Vehicle: 1:1 Ora-Sweet: Ora- } \\
\text { Plus. }\end{array}$ & 3a (amber) & $\begin{array}{l}1 \mathrm{mg} / \mathrm{mL} \text { suspension was stable } \\
\text { for } 1 \text { month at } 4{ }^{\circ} \mathrm{C} \text { and } 2 \text { weeks at } \\
25^{\circ} \mathrm{C} \text {. }\end{array}$ & \\
\hline Clozapine (15) & $1 \mathrm{a}$ & $2 d$ & $\begin{array}{l}6 \text { vehicles: Ora-Sweet; Ora-Plus; } \\
\text { 1:1 Ora-Sweet: Ora-Plus; Simple } \\
\text { syrup; 'Hospital for Sick Children } \\
\text { suspending vehicle'; and 'Guy's } \\
\text { pediatric mixture'. }\end{array}$ & $3 \mathrm{~b}$ (amber) & $\begin{array}{l}\text { 4a. } 20 \mathrm{mg} / \mathrm{mL} \text { suspensions were } \\
\text { stable for } 63 \text { days at } \\
23^{\circ} \mathrm{C} \text {. }\end{array}$ & \\
\hline $\begin{array}{l}\text { Cyclophosphamide } \\
\text { (16) }\end{array}$ & $1 d$ & $2 \mathrm{a}$ & $\begin{array}{l}2 \text { vehicles: Simple syrup; and } \\
\text { Ora-Plus. }\end{array}$ & 3c (amber) & $\begin{array}{l}\text { 4a. } 10 \mathrm{mg} / \mathrm{mL} \text { solutions were } \\
\text { stable for } 56 \text { days at } 4{ }^{\circ} \mathrm{C} \text {. Storage } \\
\text { at } 22^{\circ} \mathrm{C} \text { in Simple syrup and Ora- } \\
\text { Plus reduced stability to } 8 \text { and } 3 \\
\text { days respectively. }\end{array}$ & \\
\hline
\end{tabular}




\begin{tabular}{|c|c|c|c|c|c|c|}
\hline $\begin{array}{l}\text { Dexamethasone } \\
\text { phosphate (17) }\end{array}$ & $1 \mathrm{~d}$ & $2 a, 2 b$ & $\begin{array}{l}\text { Vehicle: 1:1 Ora-Sweet: } \\
\text { Ora-Plus. }\end{array}$ & 3b (amber) & $\begin{array}{l}\text { 4a. } 0.5 \text { and } 1.0 \mathrm{mg} / \mathrm{mL} \\
\text { suspensions were stable for } 91 \\
\text { days at } 4{ }^{\circ} \mathrm{C} \text { and } 25^{\circ} \mathrm{C} \text {. }\end{array}$ & $\begin{array}{l}\text { Commercially available } \\
\text { liquids contain alcohol or } \\
\text { their strength is lower than } \\
\text { desirable. }\end{array}$ \\
\hline Glycopyrrolate (18) & $1 \mathrm{a}$ & $2 \mathrm{a}$ & $\begin{array}{l}2 \text { vehicles: 1:1 Ora-Sweet: } \\
\text { Ora-Plus; and 1:1 Ora-Sweet } \\
\text { SF: Ora-Plus. }\end{array}$ & $3 \mathrm{~b}$ (amber) & $\begin{array}{l}\text { 4a. } 0.5 \mathrm{mg} / \mathrm{mL} \text { suspensions were } \\
\text { stable for } 90 \text { days at } 23-25^{\circ} \mathrm{C} .\end{array}$ & \\
\hline Lansoprazole (19) & $1 \mathrm{~b}$ & $2 d$ & $\begin{array}{l}2 \text { vehicles: } \mathrm{NaHCO}_{3} \text {, water; } 1^{\text {st }} \\
\text { vehicle + Ora-Sweet:Ora-Plus } \\
\text { buffered with } \mathrm{NaOH}\end{array}$ & 3a (amber) & $\begin{array}{l}4 \text { a. } 3 \mathrm{mg} / \mathrm{mL} \text { suspensions were } \\
\text { stable for } 91 \text { days at } 4{ }^{\circ} \mathrm{C} \text { and } 25 \\
{ }^{\circ} \mathrm{C} .1^{\text {st }} \text { vehicle developed a more } \\
\text { bitter taste by day } 49 \text {, however } \\
\text { this is for nasogatric and not oral } \\
\text { use. }\end{array}$ & $\begin{array}{l}\text { A } 3^{\text {rd }} \text { vehicle similar to the } \\
2^{\text {nd }} \text { vehicle but buffered } \\
\text { with } \mathrm{NaHCO}_{3} \text { was } \\
\text { deemed unpalatable. }\end{array}$ \\
\hline Lansoprazole (20) & 1a & $2 d$ & Vehicle: Ora Blend & $\begin{array}{l}\text { Clear glass } \\
\text { vial stored } \\
\text { protected } \\
\text { from light. }\end{array}$ & $\begin{array}{l}4 \text { a. } 3 \mathrm{mg} / \mathrm{mL} \text { suspension was } \\
\text { stable for } 3 \text { days at } 4.5-5.5^{\circ} \mathrm{C} \text {. } \\
\text { Storage at } 21-22^{\circ} \mathrm{C} \text { or the } \\
\text { reduction of } \mathrm{pH} \text { through addition } \\
\text { of citric acid accelerated } \\
\text { degradation of the API. }\end{array}$ & \\
\hline Levetiracetam (21) & 1a & $2 a, 2 b$ & $\begin{array}{l}\text { Vehicle: 1:1 Ora-Sweet: } \\
\text { Ora-Plus. }\end{array}$ & 3b (amber) & $\begin{array}{l}4 \text { a. } 50 \mathrm{mg} / \mathrm{mL} \text { suspensions were } \\
\text { stable for } 91 \text { days at } 4{ }^{\circ} \mathrm{C} \text { and } 25 \\
{ }^{\circ} \mathrm{C} \text {. }\end{array}$ & \\
\hline Melatonin (22) & $1 \mathrm{a}$ & $2 \mathrm{a}$ & $\begin{array}{l}2 \text { vehicles: 1:1 Ora-Sweet: } \\
\text { Ora-Plus; and 1:1 Ora-Sweet } \\
\text { SF: Ora-Plus. }\end{array}$ & $3 \mathrm{~b}$ (amber) & $\begin{array}{l}1 \mathrm{mg} / \mathrm{mL} \text { suspensions were stable } \\
\text { for } 90 \text { days at } 23-25^{\circ} \mathrm{C} \text {. Slight } \\
\text { yellow colouring occurred over } \\
\text { time. }\end{array}$ & \\
\hline $\begin{array}{l}\text { Melatonin and } \\
\text { pyridoxine } \mathrm{HCl}(22)\end{array}$ & $1 \mathrm{a}$ & $2 \mathrm{a}$ & $\begin{array}{l}2 \text { vehicles: 1:1 Ora-Sweet: } \\
\text { Ora-Plus; and 1:1 Ora-Sweet } \\
\text { SF: Ora-Plus. }\end{array}$ & $3 \mathrm{~b}$ (amber) & $\begin{array}{l}1 \mathrm{mg} / \mathrm{mL} \text { (melatonin) suspensions } \\
\text { were stable for } 90 \text { days at } 23-25 \\
{ }^{\circ} \mathrm{C} \text {. Slight yellow colouring and } \\
\text { prolonged aftertaste occurred over } \\
\text { time. }\end{array}$ & \\
\hline Mercaptopurine (23) & 1a & $2 \mathrm{a}$ & $\begin{array}{l}4 \text { vehicles: simple syrup, cherry } \\
\text { syrup, water; } 1^{\text {st }} \text { vehicle }+ \\
\text { ascorbic acid; } 1^{\text {st }} \text { vehicle }+ \\
\text { sodium phosphate; and } 1^{\text {st }} \text { vehicle } \\
+ \text { ascorbic acid and sodium } \\
\text { phosphate. }\end{array}$ & 3a (amber) & $\begin{array}{l}50 \mathrm{mg} / \mathrm{mL} \text { suspensions were } \\
\text { stable for } 35 \text { days at } 19-23^{\circ} \mathrm{C} \text {. } \\
\text { Formulations stored in a } \\
\text { refrigerator }\left(4-8^{\circ} \mathrm{C}\right) \text { showed } \\
\text { decreased stability and caking. } \\
\text { Further studies on the microbial } \\
\text { safety and efficacy of these } \\
\text { vehicles were suggested. }\end{array}$ & $\begin{array}{l}\text { API sensitive to oxidation, } \\
\text { especially at basic } \mathrm{pH} \text {. } \\
\text { Antioxidant }(0.1 \% \\
\text { ascorbic acid) increased } \\
\text { shelf life, whereas buffer } \\
\text { (sodium phosphate) } \\
\text { decreased shelf-life. }\end{array}$ \\
\hline
\end{tabular}




\begin{tabular}{|c|c|c|c|c|c|c|}
\hline Moxifloxacin (24) & $1 \mathrm{a}$ & $2 d$ & $\begin{array}{l}2 \text { vehicles: 1:1 Ora-Sweet: } \\
\text { Ora-Plus; and 1:1 Ora-Sweet } \\
\text { SF: Ora-Plus. }\end{array}$ & $3 \mathrm{~b}$ (amber) & $\begin{array}{l}4 \mathrm{a} .20 \mathrm{mg} / \mathrm{mL} \text { suspensions were } \\
\text { stable for } 90 \text { days at } 23-25^{\circ} \mathrm{C} \text {. }\end{array}$ & \\
\hline Omeprazole (25) & $1 \mathrm{f}$ & $2 d$ & Vehicle: water. & $3 \mathrm{~b}$ (amber) & $\begin{array}{l}\text { 4a. } 2 \mathrm{mg} / \mathrm{mL} \text { suspension was } \\
\text { stable for } 45 \text { days at } 3-5^{\circ} \mathrm{C} \text {. At } 45 \\
\text { days, there was a very slight } \\
\text { yellowish tint in all samples, } \\
\text { which were creamy white when } \\
\text { first prepared. }\end{array}$ & \\
\hline Omeprazole (26) & $1 \mathrm{f}$ & $2 d$ & Vehicle: water. & $\begin{array}{l}\text { Clear plastic } \\
50 \mathrm{~mL} \\
\text { conical } \\
\text { polypropyle } \\
\text { ne tubes }\end{array}$ & $\begin{array}{l}\text { 4a. } 0.6,1.2,2,3 \text { and } 4 \mathrm{mg} / \mathrm{mL} \\
\text { suspensions were stable for } 28 \\
\text { days at } 4{ }^{\circ} \mathrm{C} \text { (in the dark). Except } \\
\text { for the } 0.6 \mathrm{mg} / \mathrm{mL} \text { preparations, } \\
\text { suspensions stored at } 22-25^{\circ} \mathrm{C} \text { in } \\
\text { the light were stable for } 7 \text { days, } \\
\text { despite turning yellow. }\end{array}$ & \\
\hline Oseltamivir (6) & $1 b$ & $2 \mathrm{e}$ & $\begin{array}{l}2 \text { vehicles: Cherry Syrup and Ora- } \\
\text { Sweet SF. }\end{array}$ & $\begin{array}{l}\text { 3a (amber); } \\
3 \mathrm{~b} \text { (amber) }\end{array}$ & $\begin{array}{l}\text { 4a. } 15-\mathrm{mg} / \mathrm{mL} \text { suspensions were } \\
\text { stable for } 35 \text { days at } 5^{\circ} \mathrm{C} .2^{\text {nd }} \\
\text { vehicle was also stable for } 35 \\
\text { days at } 25^{\circ} \mathrm{C} \text { and for up to } 13 \\
\text { days at } 30^{\circ} \mathrm{C} \text {. }\end{array}$ & \\
\hline Oseltamivir (5) & $1 b$ & $2 \mathrm{e}$ & $\begin{array}{l}3 \text { vehicles: SyrSpend SF; Cherry } \\
\text { Syrup; and SyrSpend SF (for } \\
\text { reconstitution). }\end{array}$ & $3 \mathrm{~b}$ (amber) & $\begin{array}{l}4 \mathrm{a} .15-\mathrm{mg} / \mathrm{mL} \text { suspensions were } \\
\text { stable for } 30 \text { days at } 2-8^{\circ} \mathrm{C} .\end{array}$ & $\begin{array}{l}\text { Vehicles are ethanol- and } \\
\text { sorbitol-free. }\end{array}$ \\
\hline Oxandrolone (27) & $1 \mathrm{a}$ & $2 \mathrm{a}$ & $\begin{array}{l}2 \text { vehicles: 1:1 Ora-Sweet: } \\
\text { Ora-Plus; and 1:1 Ora-Sweet } \\
\text { SF: Ora-Plus. }\end{array}$ & $3 \mathrm{~b}$ (amber) & $\begin{array}{l}\text { 4a. } 1 \mathrm{mg} / \mathrm{mL} \text { suspensions were } \\
\text { stable for } 90 \text { days at } 23-25^{\circ} \mathrm{C} \text {. }\end{array}$ & $\begin{array}{l}\text { Women who are or may } \\
\text { become pregnant should } \\
\text { wear a mask when } \\
\text { compounding. }\end{array}$ \\
\hline Phenobarbital (28) & $1 \mathrm{a}$ & $2 \mathrm{a}$ & $\begin{array}{l}2 \text { vehicles: 1:1 Ora-Sweet: } \\
\text { Ora-Plus; and 1:1 Ora-Sweet } \\
\text { SF: Ora-Plus. }\end{array}$ & $3 \mathrm{~b}$ (amber) & $\begin{array}{l}4 \text { a. } 10 \mathrm{mg} / \mathrm{mL} \text { suspensions were } \\
\text { stable for } 115 \text { days at } 23-25^{\circ} \mathrm{C} \text {. }\end{array}$ & $\begin{array}{l}\text { Commercially available } \\
\text { liquid contains alcohol. }\end{array}$ \\
\hline Phenylbutyrate (29) & $1 \mathrm{f}$ & $2 \mathrm{a}$ & $\begin{array}{l}2 \text { vehicles: 1:1 Ora-Sweet: } \\
\text { Ora-Plus; and 1:1 Ora-Sweet } \\
\text { SF: Ora-Plus. }\end{array}$ & $3 \mathrm{~b}$ (amber) & $\begin{array}{l}\text { 4a. } 200 \mathrm{mg} / \mathrm{mL} \text { suspensions were } \\
\text { stable for } 90 \text { days at } 23-25^{\circ} \mathrm{C} \text {. }\end{array}$ & $\begin{array}{l}\text { Both preparations were } \\
\text { bitter with a strong, bitter } \\
\text { aftertaste. }\end{array}$ \\
\hline Rifaximin (30) & $1 \mathrm{a}$ & $2 d$ & $\begin{array}{l}2 \text { vehicles: 1:1 Ora-Sweet: } \\
\text { Ora-Plus; and 1:1 Ora-Sweet } \\
\text { SF: Ora-Plus. }\end{array}$ & $3 \mathrm{~b}$ (amber) & $\begin{array}{l}\text { 4a. } 20 \mathrm{mg} / \mathrm{mL} \text { suspensions were } \\
\text { stable for } 60 \text { days at } 23-25^{\circ} \mathrm{C} \text {. }\end{array}$ & \\
\hline Rufinamide (31) & $1 \mathrm{a}$ & $2 \mathrm{a}, 2 \mathrm{~b}$ & $\begin{array}{l}2 \text { vehicles: } 1: 1 \text { Ora-Sweet: } \\
\text { Ora-Plus; and 1:1 Ora-Sweet }\end{array}$ & $3 \mathrm{~b}$ (amber) & $\begin{array}{l}\text { 4a. } 40 \mathrm{mg} / \mathrm{mL} \text { suspensions were } \\
\text { stable for } 90 \text { days at } 23-25^{\circ} \mathrm{C} \text {. }\end{array}$ & \\
\hline
\end{tabular}


SF: Ora-Plus.

\begin{tabular}{|c|c|c|c|c|c|c|}
\hline Sulfasalazine (32) & $1 \mathrm{a}$ & $2 a, 2 b$ & Vehicle: 1:1 Ora-Sweet: Ora-Plus. & $\begin{array}{l}\text { 3a (amber); } \\
3 \mathrm{~b} \text { (PET and } \\
\text { PVC) } \\
\text { (amber) }\end{array}$ & $\begin{array}{l}100 \mathrm{mg} / \mathrm{mL} \text { suspensions were } \\
\text { stable for } 91 \text { days at } 4{ }^{\circ} \mathrm{C} \text { and } 23 \\
{ }^{\circ} \mathrm{C}\end{array}$ & \\
\hline Sunitinib (33) & $1 b$ & $2 a, 2 b$ & $\begin{array}{l}\text { Vehicle: 1:1 Ora-Sweet: Ora- } \\
\text { Plus. }\end{array}$ & $3 b$ (amber) & $\begin{array}{l}4 \mathrm{a} .10-\mathrm{mg} / \mathrm{mL} \text { suspension was } \\
\text { stable for } 60 \text { days at } 4{ }^{\circ} \mathrm{C} \text { and } \\
22^{\circ} \mathrm{C} \text {. }\end{array}$ & \\
\hline Tacrolimus (34) & $1 b$ & $2 a, 2 b$ & $\begin{array}{l}\text { Vehicle: sterile water, } 1: 1 \text { Ora- } \\
\text { Sweet: Ora-Plus. }\end{array}$ & $3 \mathrm{~b}$ (amber) & $\begin{array}{l}4 \mathrm{a} .1 \mathrm{mg} / \mathrm{mL} \text { suspension was } \\
\text { stable for } 4 \text { months at } 23-26^{\circ} \mathrm{C} \text {. }\end{array}$ & \\
\hline Tadalafil (35) & $1 \mathrm{a}$ & $2 a, 2 b$ & $\begin{array}{l}\text { Vehicle: 1:1 Ora-Sweet: Ora- } \\
\text { Plus. }\end{array}$ & $3 \mathrm{~b}$ (amber) & $\begin{array}{l}\text { 4a. } 5 \mathrm{mg} / \mathrm{mL} \text { suspension was } \\
\text { stable for } 91 \text { days at } 23-25^{\circ} \mathrm{C} \text {. }\end{array}$ & \\
\hline Temozolomide (36) & $1 b$ & $2 a, 2 b$ & $\begin{array}{l}2 \text { vehicles: citric acid, povidone } \\
\text { K-30, 1:1 Ora-Sweet: Ora-Plus; } \\
\text { and citric acid, povidone K-30, } \\
\text { 1:1 Ora-Sweet SF: Ora-Plus. }\end{array}$ & $3 \mathrm{~b}$ (amber) & $\begin{array}{l}\text { 4a. } 10 \mathrm{mg} / \mathrm{mL} \text { suspensions were } \\
\text { stable for } 60 \text { days at } 4{ }^{\circ} \mathrm{C} \text {. }\end{array}$ & $\begin{array}{l}\text { Storage at } 23{ }^{\circ} \mathrm{C} \\
\text { accelerated degradation of } \\
\text { the API. }\end{array}$ \\
\hline Thalidomide (37) & $1 b$ & $2 \mathrm{~d}$ & $\begin{array}{l}\text { Vehicle: 1:1 Ora-Sweet: Ora- } \\
\text { Plus. }\end{array}$ & $3 \mathrm{~b}$ (amber) & $\begin{array}{l}\text { 4a. } 20 \mathrm{mg} / \mathrm{mL} \text { suspension was } \\
\text { stable for } 35 \text { days at } 3-5^{\circ} \mathrm{C} \text {. }\end{array}$ & $\begin{array}{l}\text { Caregivers administering } \\
\text { the liquid should avoid } \\
\text { contact with the skin. } \\
\text { Wear gloves and a mask } \\
\text { when compounding. }\end{array}$ \\
\hline Thalidomide (38) & $1 b$ & $2 \mathrm{~d}$ & $\begin{array}{l}\text { Vehicle : tragacanth mucilage, } \\
\text { sorbitol compound syrup, benzoic } \\
\text { acid } 5 \% \text { solution, citric acid, } \\
\text { distilled water. }\end{array}$ & $\begin{array}{l}\text { Amber } \\
\text { bottles }\end{array}$ & $\begin{array}{l}\text { 4a. } 10 \mathrm{mg} / \mathrm{mL} \text { suspensions were } \\
\text { stable for } 31 \text { days at } 21-23^{\circ} \mathrm{C} \text {. }\end{array}$ & $\begin{array}{l}\text { See warnings above } \\
\text { regarding protective } \\
\text { measures. }\end{array}$ \\
\hline Thioguanine (39) & $1 \mathrm{a}$ & $2 \mathrm{a}$ & $\begin{array}{l}3 \text { vehicles: Simple syrup and } \\
\text { methylcellulose; Ora-Sweet and } \\
\text { Ora-Plus; and } 2^{\text {nd }} \text { vehicle }+ \\
\text { ascorbic acid. }\end{array}$ & 3a (amber) & $\begin{array}{l}20 \mathrm{mg} / \mathrm{mL} \text { suspensions were } \\
\text { stable for } 63 \text { days at } 19-23^{\circ} \mathrm{C} . \mathrm{pH} \\
\text { increased over the study period. }\end{array}$ & $\begin{array}{l}\text { Addition of antioxidant } \\
(0.1 \% \text { ascorbic acid) was } \\
\text { not effective in } \\
\text { consistently increasing } \\
\text { shelf-life. }\end{array}$ \\
\hline Vancomycin (40) & $1 d$ & $2 a, 2 b$ & Vehicle: SyrSpend SF & $3 b$ (amber) & $\begin{array}{l}50 \mathrm{mg} / \mathrm{mL} \text { suspension was stable } \\
\text { for } 90 \text { days at } 2-8^{\circ} \mathrm{C} \text {. }\end{array}$ & $\begin{array}{l}\text { Vehicle is ethanol- and } \\
\text { sorbitol-free. }\end{array}$ \\
\hline Venlafaxine (41) & $1 b$ & $2 \mathrm{~d}$ & $\begin{array}{l}2 \text { vehicles: 1:1 Ora-Sweet: } \\
\text { Ora-Plus; and Simple syrup. }\end{array}$ & $3 \mathrm{~b}$ (amber) & $\begin{array}{l}\text { 4a. } 15 \mathrm{mg} / \mathrm{mL} \text { suspension was } \\
\text { stable for } 28 \text { days at } 5^{\circ} \mathrm{C} \text { and } 23 \\
{ }^{\circ} \mathrm{C} \text {. }\end{array}$ & $\begin{array}{l}\text { The capsules were a slow } \\
\text { release dosage form. } \\
\text { Capsule microspheres } \\
\text { were ground to a powder. }\end{array}$ \\
\hline Venlafaxine (42) & $1 \mathrm{a}$ & $2 \mathrm{a}, 2 \mathrm{~b}$ & $\begin{array}{l}\text { Vehicle: 1:1 Ora-Sweet: Ora- } \\
\text { Plus. }\end{array}$ & $3 a$ (amber) & $\begin{array}{l}\text { 4a. } 5 \mathrm{mg} / \mathrm{mL} \text { suspension was } \\
\text { stable for } 15 \text { days at } 4{ }^{\circ} \mathrm{C} \text { and } 10 \\
\text { days at } 22-28^{\circ} \mathrm{C} \text {. }\end{array}$ & \\
\hline
\end{tabular}




\begin{tabular}{|c|c|c|c|c|c|c|}
\hline Venlafaxine (43) & $1 b$ & $2 \mathrm{c}$ & $\begin{array}{l}2 \text { vehicles: tragacanth mucilage, } \\
\text { sorbitol compound syrup, benzoic } \\
\text { acid } 5 \% \text { solution, distilled water; } \\
\text { and } 1^{\text {st }} \text { vehicle without tragacanth } \\
\text { mucilage. }\end{array}$ & 3a (amber) & $\begin{array}{l}\text { 4a. } 7.5 \mathrm{mg} / \mathrm{mL} \text { suspensions were } \\
\text { stable for } 30 \text { days at } 20-24^{\circ} \mathrm{C} .\end{array}$ & $\begin{array}{l}\text { The capsules were a slow } \\
\text { release dosage form. } \\
\text { Capsule microspheres } \\
\text { were ground to a powder. }\end{array}$ \\
\hline Warfarin (44) & $1 \mathrm{a}$ & $2 \mathrm{~d}$ & $\begin{array}{l}\text { Vehicle: Sodium phosphate, } \\
\text { tragacanth mucilage, sorbitol } \\
\text { compound syrup, Compound } \\
\text { Hydroxybenzoate Solution APF } \\
\text { (methyl and ropyl } \\
\text { hydroxybenzoate, propylene } \\
\text { glycol), distilled water. }\end{array}$ & $3 a$ (amber) & $\begin{array}{l}4 \mathrm{a} .1 \mathrm{mg} / \mathrm{mL} \text { suspensions were } \\
\text { stable for } 28 \text { days at } 20-24^{\circ} \mathrm{C} \text {. }\end{array}$ & $\begin{array}{l}\text { Warfarin is subject to } \mathrm{pH}- \\
\text { dependent sorption to } \\
\text { polyvinyl chloride plastic. } \\
\text { (1) }\end{array}$ \\
\hline $\begin{array}{l}\text { Ziprasidone mesylate } \\
(45)\end{array}$ & $1 d$ & $2 \mathrm{a}$ & Vehicle: Ora-Sweet. & $3 b$ (amber) & $\begin{array}{l}\text { 4a. } 2.5 \mathrm{mg} / \mathrm{mL} \text { solution was stable } \\
\text { for } 6 \text { weeks at } 5^{\circ} \mathrm{C} \text {. Storage in the } \\
\text { light or at } 20-22^{\circ} \mathrm{C} \text { accelerated } \\
\text { degradation of the API. }\end{array}$ & $\begin{array}{l}\text { The API is solubilised by } \\
\text { complexation with } \beta \text { - } \\
\text { cyclodextrin in the I/V } \\
\text { preparation. }\end{array}$ \\
\hline Zonisamide (46) & $1 b$ & $2 \mathrm{~d}$ & $\begin{array}{l}2 \text { vehicles: Simple syrup NF; and } \\
0.5 \% \text { methylcellulose. }\end{array}$ & $3 \mathrm{~b}$ (amber) & $\begin{array}{l}4 \mathrm{a} .10 \mathrm{mg} / \mathrm{mL} \text { suspension was } \\
\text { stable for } 28 \text { days at } 3-5^{\circ} \mathrm{C} \text { and } \\
23-25^{\circ} \mathrm{C} \text { in the } 1^{\text {st }} \text { vehicle, and } 28 \\
\text { days at } 3-5^{\circ} \mathrm{C} \text { and } 7 \text { days at } 23-25 \\
{ }^{\circ} \mathrm{C} \text { in the } 2^{\text {nd }} \text { vehicle. }\end{array}$ & $\begin{array}{l}\text { Significant microbial } \\
\text { growth was observed in } \\
\text { methylcellulose vehicle } \\
\text { stored at } 23-25^{\circ} \mathrm{C} \text { after } 7 \\
\text { days. }\end{array}$ \\
\hline $\begin{array}{l}\text { 1a. Tablet modified to } \\
\text { 1b. Capsule modified } \\
\text { 1c. Liquid-filled soft g } \\
\text { 1d. I/V preparation mo } \\
\text { 1e. Inhalation preparat } \\
\text { 1f. Granular powder p } \\
\text { 2a. Lack of a commer } \\
\text { 2b. Ease of administra } \\
\text { 2c. Nasogastric, jejun } \\
\text { 2d. All of the above - } \\
\text { 2e. Commercial oral li } \\
\text { * Unpleasant sulfurou } \\
\text { and have difficulties a } \\
\text { 3a. Glass prescription } \\
\text { 3b. Plastic prescriptior } \\
\text { 3c. Plastic oral syring } \\
\text { 4a. Analysis of organo }\end{array}$ & $\begin{array}{l}\text { n ora } \\
\text { an o } \\
\text { latin } \\
\text { ified } \\
\text { n m } \\
\text { para } \\
\text { ally a } \\
\text { on du } \\
\text { or fe } \\
\text { e. or } \\
\text { did d } \\
\text { smel } \\
\text { erin } \\
\text { tttles } \\
\text { pottle }\end{array}$ & $\begin{array}{l}\text { mix } \\
\text { id m } \\
\text { mo } \\
\text { ral li } \\
\text { to an } \\
\text { difie } \\
\text { e ora } \\
\text { allo } \\
\text { ubes } \\
\text { dos } \\
\text { orm } \\
\text { ste o } \\
\text { ner o }\end{array}$ & $\begin{array}{l}\text { o an oral liquid mixture } \\
\text { ixture } \\
\text { quid mixture } \\
\text { oral liquid mixture } \\
\text { (paediatric) formulation for dose ac } \\
\text { ifficulties } \\
\text { m not commercially available; inclu } \\
\text { tinued or unavailable } \\
\text { ug resulting from the slow release o } \\
\text { nhalation therapy. }\end{array}$ & hydrogen sul & $\begin{array}{l}\text { ing to body weight or swallowing di } \\
\text { uiring a non-standard dose. } \\
\text { le gas. As a result, patients may expe }\end{array}$ & $\begin{array}{l}\text { ience nausea and vomiting } \\
\text { ouring/ redistribution, }\end{array}$ \\
\hline
\end{tabular}

